\title{
Trace Metal Cycling in the Upper Sedimentary Redox Zones in an Ocean Desert
}

\author{
N. RIEDINGER ${ }^{1}$, C.K. JONES ${ }^{1}$, M. KÖSTER ${ }^{2}$, G. \\ BOHRMANN $^{3}$, F.S. COLWELL ${ }^{4}$, AND M.E. TORRES ${ }^{4}$ \\ ${ }^{1}$ Boone Pickens School of Geology, Oklahoma State \\ University, Stillwater, OK 74074, USA, \\ natascha.riedinger@okstate.edu; \\ christopher.k.jones@okstate.edu \\ ${ }^{2}$ Alfred Wegener Institute, Helmholtz Centre for Polar and \\ Marine Research, 27570 Bremerhaven, Germany, \\ male.koester@awi.de \\ ${ }^{3}$ MARUM - Center for Marine Environmental Sciences, \\ University of Bremen, 28359 Bremen, Germany, \\ gbohrmann@marum.de \\ ${ }^{4}$ College of Earth, Ocean, and Atmospheric Sciences, Oregon \\ State University, Corvallis, OR 97331, USA, \\ marta.torres@oregonstate.edu, \\ rick.colwell@oregonstate.edu
}

Specific trace metals are often applied as paleoceanographic proxies to reconstruct water column redox conditions or productivity. Some of these metals have been reported to co-react with other, more abundant metals during early diagenetic alteration. For example, metals such as molybdenum, copper, and cobalt have been described to adsorb or be released into the pore water during the cycling of manganese $(\mathrm{Mn})$ and iron $(\mathrm{Fe})$ oxides, while nickel and silver appear to be tied to the organic-pool, and uranium is assumed to diffuse into the sediment in the upper redox layers. Here we present high resolution trace metal profiles from the upper redox zones in an organic carbon starved system. Investigated gravity and multi-corer cores were retrieved near the East Scotia Ridge during R/V Polarstern Expedition PS119 to the Scotia Sea. The organic-poor sediments are characterized by high contents of diatomaceous ooze and reactive $\mathrm{Mn}$ - and $\mathrm{Fe}$ - oxides. Nearby active hydrothermal vents additionally deliver various trace metals to the sediments. Our preliminary data reveal remobilization of iron and manganese oxides several meters below the sediment surface. Pore water profiles of trace metals such as vanadium, cobalt, and copper indicate cycling independent of the $\mathrm{Mn}$ - and $\mathrm{Fe}$ - oxide phases. The pore water vanadium profile shows inverse iron trends, while silver spikes in the oxic zone and again at the onset of iron reduction where iron is released into the pore water. These observed metal trends could provide a roadmap for further, specific metal targeted microbial studies and add in the development and/or refinement of paleoceanographic proxy tools. 